\title{
2021 Handbook of Florida Water Regulation: Solid Waste Management ${ }^{1}$
}

\author{
Michael T. Olexa, Tatiana Boriosva, and Jana Caracciolo
}

\section{Preface}

This handbook is designed to provide an accurate, current, and authoritative summary of the principal federal and state (Florida) laws that directly or indirectly relate to agriculture. This handbook provides a basic overview of the many rights and responsibilities that farmers and farmland owners have under both federal and state laws as well as the appropriate contact information to obtain more detailed information. However, the reader should be aware that because the laws, administrative rulings, and court decisions on which this handbook is based are subject to constant revision, portions of this publication could become outdated at any time. Several details of cited laws are also left out due to space limitations. This handbook is provided as an educational text for those interested in water use and water resource issues in Florida.

This handbook is distributed with the understanding that the authors are not engaged in rendering legal or other professional advice, and the information contained herein should not be regarded as a substitute for professional advice. This handbook is not all inclusive in providing information to achieve compliance with the federal and state laws and regulations governing water protection. For these reasons, the use of these materials by any person constitutes an agreement to hold harmless the authors, the UF/IFAS Center for Agricultural and Natural Resource Law, and UF/IFAS Extension for any liability claims, damages, or expenses that may be incurred by any person as a result of reference to or reliance on the information contained in this handbook. Note: UF/IFAS is the acronym for University of Florida, Institute of Food and Agricultural Sciences.

\section{SWM Overview}

\section{Who regulates solid waste management?}

Both federal and state governments have enacted Resource Conservation and Recovery Act (RCRA) legislation to deal with the disposal of solid wastes. The federal rules are administered by the United States Environmental Protection Agency (EPA) and the state rules are administered by the Florida Department of Environmental Protection (FDEP) for solid waste management (SWM).

Both federal and state RCRAs are aimed at protecting public health and the environment, and at recycling or reclaiming solid wastes to the greatest extent practicable. Because improperly handled solid waste (e.g., residues generated during the treatment of domestic wastewater, or used oil) represents such a grave threat to water quality, it also falls within the scope of other federal regulations, most notably the National Pollutant Discharge Elimination System (NPDES) of the federal Clean Water Act. NPDES is both an EPA-enforced and state-enforced system requiring permits for all point source pollution discharges into navigable

1. This document is FE611, one of a series of the Food and Resource Economics Department, UF/IFAS Extension. Original publication date October. Revised June 2017 and April 2021. Visit the EDIS website at https://edis.ifas.ufl.edu for the currently supported version of this publication.

2. Michael T. Olexa, professor, Food and Resource Economics Department, and director, UF/IFAS Center for Agricultural and Natural Resource Law; Tatiana Borisova, associate professor, Food and Resource Economics Department; and Jana Caracciolo, student, Levin College of Law; UF/IFAS Extension, Gainesville, FL 32611.

The Institute of Food and Agricultural Sciences (IFAS) is an Equal Opportunity Institution authorized to provide research, educational information and other services

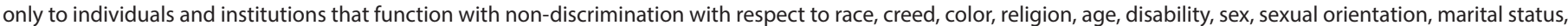

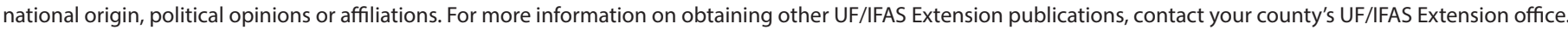
U.S. Department of Agriculture, UF/IFAS Extension Service, University of Florida, IFAS, Florida A \& M University Cooperative Extension Program, and Boards of County Commissioners Cooperating. Nick T. Place, dean for UF/IFAS Extension. 
waters (see FE602, Groundwater Discharge Regulation at the Federal Level; the broad definition of "navigable waters" is covered in FE582, CWA). Point sources are those that can be specifically identified (as opposed to nonpoint sources, such as a diffuse runoff over a large area of land). Under the federal Clean Water Act, Confined Animal Feeding Operations (CAFOs) are considered to be a type of point source, requiring NPDES permits before they are allowed to operate.

Aside from the areas of special state and federal interest, local authorities are basically free to set their own rules, within broad state guidelines, for the collection and disposal of solid wastes. Cities, counties, and/or municipalities should be consulted regarding problems involving the locations of disposal facilities, frequency of waste pickup, and other day-to-day waste disposal questions.

\section{What is solid waste?}

Solid waste is classified by the federal RCRA in two categories: (1) any garbage, refuse, sludge, or other discarded materials and (2) liquid, semi-solid, or contained gaseous materials. Furthermore, waste from agricultural activities is explicitly included in the definition of solid wastes.

A few examples of materials that are explicitly listed as not within the RCRA definition of solid waste are as follows:

- Solid or dissolved materials in domestic sewage

- Solid or dissolved waste from irrigation return flows

- Industrial discharges from point sources which are permitted for release under the NPDES of the Clean Water Act

- Source, special nuclear, or byproduct material as defined by the Atomic Energy Act of 1954

For a complete list of wastes that are excluded from the definition of solid waste, visit the EPA website (https:// www.epa.gov/hw/criteria-definition-solid-waste-and-solidand-hazardous-waste-exclusions).

If none of these exceptions apply and if the material involved may be said to be discarded or to have served its useful purpose, it is a solid waste. Solid waste may be recycled, reused, discarded, reclaimed, or stored, depending on its nature. Many solid wastes may also be hazardous wastes and subject to other, more restrictive regulations (see FE612, Hazardous Waste Management).
NPDES coverage extends only to discharges into navigable waters and sets different standards for the amount of waste that may be discharged based on:

- The type of industry involved

- The toxicity of the waste

- The acceptable maximum amounts of harmful elements that can be released into the body of water that is being polluted

Facilities violate the law if they dispose of waste in any way not in accordance with the federal RCRA guidelines or NPDES requirements for discharging wastewater.

\section{What are residuals?}

FDEP has established detailed regulations controlling the application of residuals (sewage sludge) to land. Residuals are solid, liquid, or semisolid residues generated during the treatment of domestic wastewater in a domestic wastewater treatment facility. Residuals can be applied to land only if the facility generating or treating the residuals has a valid NPDES permit that includes an approved Agricultural Use Plan for the application site. Residuals for land application are classified as either Class AA, Class A, or Class B with respect to the pathogen reduction requirements set forth by EPA as follows:

- Class AA Residuals are treated to eliminate pathogens and meet strict pollutant criteria. They may be used without restriction and sold to the public.

- Class A residuals contain no detectible levels of pathogens. They are allowed on unrestricted public areas, such as playgrounds, parks, golf courses, lawns, and hospital grounds.

- Class B residuals are only allowed in restricted public access areas, such agricultural sites, forests, and roadway shoulders and medians. The public shall be restricted from the application zone for twelve months after the last application of the residuals. Additional restrictions apply when residuals are applied to soil in which food crops are grown and harvested and where animals graze on the application site.

Cautions that apply to the use or disposal of residuals include the following:

- Residuals may never be dumped into oceans, or groundwater or surface waters

- Residuals must not be discharged into a collection or transmission system without prior consent of the owner of that system 
- Residuals containing hazardous wastes may never be applied to agricultural lands, and may require disposal under more restrictive, hazardous waste regulations

- Residuals may never cause the violation of surface water quality standards (For more information on surface water quality standards, see Management and Storage of Surface Waters (FE605))

\section{How is used oil regulated?}

Both state and federal laws are consistent in their prohibitions against the haphazard disposal of used oil. It is clearly a violation to

- Discharge oil into soils, sewers, drainage systems, septic tanks, groundwater, surface waters, watercourses, or marine waters

- Dispose of oil in a landfill, or commingle (mix) oil with other wastes for the purpose of disposing of it in a landfill

- Commingle (mix) used oil with hazardous substances that make the used oil unsuitable for recycling or beneficial use

- Release used oil into the environment through any process, including weed control, dust control, road oiling, or other similar uses

Furthermore, all processors and transporters of used oil must register with FDEP annually, and all facilities for handling used oil must obtain FDEP permits.

\section{What can be composted from waste?}

The FDEP has established detailed regulations for the production and use of compost created from waste. The scope of these regulations does not encompass the use of compost obtained from normal farming operations on the land where it was generated.

Rules for when you may compost:

- You may compost wastes produced in "normal farming operations" such as activities used in the production of poultry, livestock, or agricultural crops (normal waste from these operations includes organic waste, manure, and wastes derived solely from agricultural crops)

- As long as you have obtained permits from the FDEP and complied with detailed FDEP regulations, you may produce compost for sale

Rules for when you may not compost:

- You may not use solid waste as fill material in any body of surface water
- You may not compost biohazardous wastes, mechanical wastes, chemical wastes, or asbestos-containing wastes, except in the small quantities normally found in household waste

- FDEP regulations prohibit any application of compost that would endanger public health or the environment

\section{What should not go into landfills?}

Florida has taken an interest in limiting the types of solid waste to be disposed of through landfills and has specifically prohibited the use of landfills to dump:

- Used oil

- Lead-acid batteries

- Yard trash

- White goods (e.g., discarded appliances such as refrigerators or water heaters)

The burning of solid waste is also prohibited except under the conditions expressly approved by the rules for disposal facilities.

\section{Sources}

42 United States Code, Sections 6901 to 6987

40 Code of Federal Regulations, Section 240, et seq.

33 United States Code, Sections 1251 to 1387

Chapter 403, Florida Statutes, Sections 403.702 to 403.7893

Title 17, Florida Administrative Code

\section{Acknowledgments}

The authors are indebted to the personnel of both state and federal agencies who provided their time and advice in the preparation of this handbook. We acknowledge Carol Fountain and Susan Gildersleeve at the University of Florida for their assistance in editing this handbook. We also acknowledge funding received for updating this publication from the James S. and Dorothy F. Wershow Agricultural Law Endowment. 